\title{
A alcalinização do solo aumenta o potencial invasivo de uma gramínea exótica no cerrado?
}

\author{
Luísa L. F. Pecoral ${ }^{\star}$, Cleiton B. Eller, Gabriel Wolfsdorf, Larissa S. Verona, Patricia B. Costa, Rafael S. Oliveira
}

\section{Resumo}

O domínio cerrado é considerado um "hotspot" de biodiversidade e sua integridade e diversidade de espécies estão fortemente ameaçadas por mudanças de uso da terra em grande escala e pela invasão de espécies de gramíneas de origem africana. As gramíneas africanas têm o potencial de afetar funções ecossistêmicas, alterando a produtividade, estrutura trófica, o microclima, a disponibilidade de recursos e as interações competitivas. A alta disponibilidade de nutrientes no solo pode favorecer a invasão de espécies exóticas de rápido crescimento, superando espécies nativas do Cerrado. O objetivo desse projeto é entender a influência da alcalinização do solo na capacidade competitiva de uma gramínea exótica invasora (Urochloa decumbens) e uma gramínea nativa. Com o tratamento de calagem do solo, buscamos aumentar a disponibilidade de nutrientes para favorecer o desenvolvimento de U. decumbens em detrimento do Andropogon fastigiatus, gramínea nativa muito abundante em áreas em processo de restauração.

\section{Palavras-chave:}

\section{Competição, Restauração, Poaceae.}

\section{Introdução}

A expansão agropecuária e urbana, a exploração irracional da água e o uso indiscriminado do fogo estão levando ao desaparecimento de espécies de plantas de importância econômica e ecológica, nativas do cerrado. Gramíneas africanas foram utilizadas para o plantio de pastagens em todo o território, tendo sido selecionadas por apresentarem alta produtividade diante de condições de fertilização" .

Considerando que a flora do Cerrado evoluiu em solos pobres em nutrientes ${ }^{2}$, com altas concentrações de alumínio e alta acidez, o aumento na disponibilidade de nutrientes pode favorecer a invasão de espécies exóticas de rápido crescimento, superando espécies nativas do Cerrado $^{3}$, consideradas plantas de crescimento lento em sua maioria. $\mathrm{O}$ objetivo desse projeto é avaliar como a alcalinização do solo afeta atributos funcionais e o crescimento de gramíneas exóticas invasoras e gramíneas nativas do cerrado. Para tanto, formulamos a hipótese de que o desenvolvimento da espécie $U$. decumbens é facilitado em solos mais alcalinos, se tornando melhor competidora por apresentar maiores taxas de crescimento, enquanto que $A$. fastigiatus terá sua capacidade de competir prejudicada, que será refletida em menor taxa de crescimento. Espera-se observar o aumento da capacidade invasora de $U$. decumbens, ao desenvolver uma maior biomassa aérea e radicular, em detrimento de $A$. fastigiatus, uma vez que a gramínea exótica evoluiu em condições do solo típicos da savana africana, com menor acidez e consequentemente, maior disponibilidade de nutrientes ${ }^{4}$.

\section{Resultados e Discussão}

O experimento foi realizado em casa de vegetação, e foi utilizado o procedimento de calagem para alcalinização do solo. A gramínea nativa $A$. fastigiatus apresentou taxa de crescimento relativo mais alta que a gramínea exótica. Além disso, observamos que esta espécie tem ciclo de vida anual, ao contrario de outras espécies nativas do Cerrado que são perenes e de crescimento lento. Por conta dessas características, observamos que a espécie nativa cresceu mais e apresentou maior plasticidade fenotípica em resposta ao tratamento de alcalinização que a espécie exótica.
Considerando a taxa de crescimento como a principal característica para predizer as respostas da planta, foi possível observar a diversidade de estratégias de crescimento em gramíneas do cerrado. Dessa forma, essa espécie nativa pode ser considerada uma boa competidora em relação a espécies exóticas de crescimento rápido.

\section{Conclusões}

A espécie nativa $A$. fastigiatus tem grande potencial de ser usada com sucesso em áreas de restauração cujo solo sofreu processo de calagem, pois esta é uma das poucas espécies que tem alta capacidade competitiva em ambientes com alta disponibilidade de nutrientes. Estes resultados contribuirão para o desenvolvimento de técnicas de restauração que visam potencializar o estabelecimento de gramíneas nativas em detrimento de $U$. decumbens baseadas em modificações no $\mathrm{pH}$ do solo. Ainda contribuirão com pesquisas em andamento no Parque Nacional da Chapada dos Veadeiros, obtendo respostas práticas para a restauração de áreas do cerrado a partir de antigos campos de pastagem já instalados e dominados por gramíneas invasoras. Recomendamos a realização de novos experimentos utilizando plantas nativas de crescimento lento, como previsto inicialmente no projeto.

\section{Agradecimentos}

Ao meu orientador Prof. Dr. Rafael S. Oliveira, que possibilitou a realização do projeto, ao CNPq (Conselho Nacional de Desenvolvimento Científico e Tecnológico) pela bolsa de estudos, à FAPESP e a CAPES pelo auxílio no financiamento do projeto, e à minha amiga Larissa S. Verona, que me acompanhou em todos os procedimentos realizados.

${ }^{1}$ BERGOLI, Luís Michel Goularte. Desempenho de forrageiras tropicais sob irrigação. 2013.

${ }^{4}$ BUSTAMANTE, M. M. C. et al. Nitrogen cycling in tropical and temperate savannas. In: Nitrogen Cycling in the Americas: Natural and Anthropogenic Influences and Controls. Springer Netherlands, 2006. p. 209-237.

${ }^{3}$ ELLER, Cleiton B.; OLIVEIRA, Rafael S. Effects of nitrogen availability on the competitive interactions between an invasive and a native grass from Brazilian cerrado. Plant and Soil, v. 410, n. 1-2, p. 63-72, 2017.

${ }^{2}$ PEREIRA, Caio G. et al. Underground leaves of Philcoxia trap and digest nematodes. Proceedings of the National Academy of Sciences, v. 109, n. 4, p. 1154-1158, 2012. 